\title{
Anemia among indigenous women in Brazil: findings from the First National Survey of Indigenous People's Health and Nutrition
}

Maria Carolina Borges ${ }^{1}$, Romina Buffarini ${ }^{1}$, Ricardo V. Santos ${ }^{2,3}$, Andrey M. Cardoso ${ }^{2}$, James R. Welch², Luiza Garnelo ${ }^{4}$, Carlos E. A. Coimbra Jr..$^{2^{*}}$ and Bernardo L. Horta ${ }^{1}$

\begin{abstract}
Background: Anemia is recognized as a major public health problem that disproportionately affects vulnerable populations. Indigenous women of reproductive age in Brazil are thought to be at high risk, but lack of nationwide data limits knowledge about the burden of disease and its main determinants. This study aimed to assess the prevalence of anemia and associated factors in this population using data from The First National Survey of Indigenous People's Health and Nutrition in Brazil.

Methods: Data were collected from Indigenous women between 15 and 49 years old based on a nationwide sample of villages. The outcomes of interest were hemoglobin levels $(\mathrm{g} / \mathrm{dL})$ and anemia $(<12 \mathrm{~g} / \mathrm{dL}$ for nonpregnant and $<11 \mathrm{~g} / \mathrm{dL}$ for pregnant women). Multilevel models were used to explore associations with contextual (village) and individual (household/woman) level variables.

Results: Based on data for 6692 Indigenous women, the nationwide mean hemoglobin level was $12.39 \mathrm{~g} / \mathrm{dL}$ (95\% Cl: 12.29-12.50). Anemia prevalence was high (33.0\%; $95 \%$ Cl: 30.40-35.61 \%) and showed pronounced regional disparities. No village-level characteristics were associated with anemia or hemoglobin levels in the multilevel model. Even after controlling for upper level variables, socioeconomic status, parity, body mass index, and having been treated for malaria were associated with anemia and hemoglobin levels.

Conclusion: The prevalence of anemia in Brazilian Indigenous women was $12 \%$ greater than the national estimates for women of reproductive age. Anemia prevalence and mean hemoglobin levels among Indigenous women appear to be partly explained by some previously recognized risk factors, such as socioeconomic status, body mass index, and malaria; however, part of the variability in these outcomes remains unexplained. Knowledge of health status and its potential determinants is essential to guide public policies aimed at controlling anemia burden in Indigenous communities.
\end{abstract}

Keywords: Brazil, Indigenous peoples, Health surveys, Nutrition surveys, Health status indicators, Anemia, Maternal health

\footnotetext{
* Correspondence: coimbra@ensp.fiocruz.br

Escola Nacional de Saúde Pública, Fundação Oswaldo Cruz, Rua Leopoldo

Bulhões 1480, Rio de Janeiro, RJ 21041-210, Brazil

Full list of author information is available at the end of the article
} 


\section{Background}

Anemia is recognized as a major public health problem, affecting over 1.2 billion people worldwide [1]. It has been estimated that more than one third of women of reproductive age suffer from anemia globally, with this burden falling disproportionately on those in low- and middle-income countries [2]. Maternal anemia has wellestablished short- and long-term consequences for both mother and child, decreasing the chance of survival and increasing the risk of poor fetal growth and complications during pregnancy and the perinatal period [3].

Brazil has undergone major changes in social determinants of health and in the organization of health systems in recent decades $[4,5]$. However, Indigenous peoples, one of the most vulnerable groups in the country, still experience high rates of morbidity and mortality due to infectious and parasitic diseases, food insecurity, as well as poor sanitation and housing conditions [6-8].

Previous studies have found that anemia is highly prevalent in Indigenous populations in Brazil, especially among children [9, 10]. There is limited information available on the epidemiology of anemia among adult Indigenous women, despite the vulnerabilities of this group, which often include bearing a first child at an early age and high parity throughout their reproductive years [11-13]. Among the Xavante Indians from Central Brazil, $54.2 \%$ of adult women from $20-40$ years of age had anemia [14]. In the Suruí from Southern Amazonia, anemia prevalence rates of $67.3 \%$ and $81.8 \%$ were observed for non-pregnant and pregnant women, respectively, in conjunction with a negative association between the occurrence of anemia and socioeconomic status [15].

The First National Survey of Indigenous People's Health and Nutrition in Brazil (henceforth, "National Survey"), conducted in 2008-2009, was the first and most comprehensive study to investigate nutritional status based on a nationwide representative sample of Indigenous women (14-49 years of age) and children ( $<5$ years of age) in the country [16]. The present article used National Survey data in order to assess the prevalence of anemia, mean hemoglobin levels and associated factors among Indigenous women.

\section{Methods}

\section{The National Survey}

The National Survey employed a multistage sampling to obtain a representative sample of the country's official geopolitical regions North, Northeast, Central-West, and South/Southeast (the South and Southeast regions were joined) based on a list of Indigenous villages provided in 2008 by the Brazilian National Health Foundation (Fundação Nacional de Saúde - FUNASA) [16]. The original list contained 3995 villages located in federally recognized Indigenous Reserves, from which 1227 were excluded for being vacated, deactivated, or having less than 31 inhabitants, which was the minimum village size number investigated.

The sample size for each region was calculated using the following parameters: a prevalence of $50 \%$ for all disease outcomes, a relative error of $5 \%$ and a confidence interval of $95 \%$, according to the methodology proposed by Lemeshow [17]. Sequential Poisson Sampling criteria were used to select villages for inclusion in the study, based on the calculated sample size for each region [18]. The final sample consisted of 123 villages distributed by region as follows: 65 (North), 14 (Central-West), 23 (Northeast), and 21(South/Southeast). In villages with a population of less than 150 eligible individuals, all households were investigated, while, in those with more than 150 eligible individuals, households were selected systematically. The present analysis is based on data collected for women from 14 to 49 years of age.

Of the four questionnaires applied in the National Survey (village, household, woman, child), the data used in this paper derive from the first three. Questions in Portuguese addressed sociodemographic conditions, sanitation, domestic economy, access to health services, and maternal characteristics, among others. Local Indigenous translators (often Indigenous health agents or primary education teachers) were used for interviews with nonPortuguese speaking respondents. For the assessment of hemoglobin, one drop of capillary blood was obtained with one-way lancets fitted to an Accu-Chek lancing device by Roche (Mannheim, Germany) and analyzed using portable hemoglobinometer, model HemoCue $\mathrm{Hb} 201+$ (Ängelholm, Sweden). Body weight was measured to the nearest $100 \mathrm{~g}$ with a portable digital scale (Seca model 872, Hamburg, Germany), with participants wearing minimal clothing and barefoot. Standing height was measured with an AlturaExata portable anthropometer (Belo Horizonte, Brazil) and recorded to the nearest $0.1 \mathrm{~cm}$. Previously trained and standardized field researchers carried out anthropometric measurements. A detailed description of the methods used in the National Survey is presented elsewhere [16].

\section{Study variables}

Hemoglobin levels were considered as a continuous $(\mathrm{g} / \mathrm{dL})$ as well as a dichotomous variable (anemia: $<12 \mathrm{~g} / \mathrm{dL}$ for nonpregnant and $<11 \mathrm{~g} / \mathrm{dL}$ for pregnant women) [1].

Contextual village-level independent variables included access to government social programs related to economic production (Indigenous Initiatives Project Carteira Indígena), community healthcare (Indigenous Community Healthcare Initiatives Project - Projeto Iniciativas Comunitárias em Saúde Indígena), and food security (Food Acquisition Project - Programa de 
Aquisição de Alimentos) in the three years prior to the interview.

Household-level independent variables included information on socioeconomic status (household goods index and regular income), living conditions (housing condition and sanitation indices), and food patterns (household consumption/production and seasonal shortages). Regular household income was defined as presence of monthly or annually income from salaries, pensions, or social benefits.

Principal component analysis was used to create the following socioeconomic and living condition variables: (a) household goods index, based on the quantities of durable goods in each household $\left(1^{\text {st }}\right.$ component explained $19 \%$ of variance, eigenvalue: 3.56); (b) housing conditions index, based on type of flooring, walls, roofing, presence of electricity, and fuel used for cooking $\left(1^{\text {st }}\right.$ component explained $48.0 \%$ of variance, eigenvalue: 1.44); and (c) sanitation index, based on primary defecation location, trash disposal destination, primary source of drinking water, and availability of filtered water in the house $\left(1^{\text {st }}\right.$ component explained $56.5 \%$ of variance, eigenvalue: 0.63). Households received scores based on the sum of the contribution of each item multiplied by the quantity of each item before being classified according to tertiles of the combined distribution, considering the four regions combined.

Principal component analysis was also utilized to derive household food consumption and production patterns using 14 food items: rice, corn, manioc, tubers (sweet potatoes and yams), beans, fruits, nuts, vegetables, milk, egg, chicken, beef, game, and fish. Varimax rotation was used to improve component interpretation. The first three components were considered after the analysis of the scree plot, which together explained $44.6 \%$ of the variability. Food items were considered representative of each component if they showed a loading greater than 0.3 . Household scores were calculated following the same methodology described above for three subsets of food items: purchased foods index (rice, beans, milk, egg, chicken, and beef purchased within or outside the village); wild foods index (nuts, game, and fish obtained locally by fishing, gathering, and hunting); garden produce index (corn, manioc, tubers, and fruits produced in Indigenous gardens).

Individual-level variables included age group (14-19, 20-34, and 35-49 years), schooling (none, primary, secondary, and tertiary education), body mass index (BMI) (underweight, normal weight, overweight, and obese), parity (number of children ever born), previous treatment for malaria (yes/no), and currently pregnant (yes/no). BMI cutoffs were defined separately for individuals 20 years or more [19] and those 14 to 19 years [20, 21]. For the subset of women with at least one child under 5 years, the following variables about antenatal care during the last pregnancy were included: at least one antenatal care consultation (yes/no), at least 3 tetanus vaccination doses (yes/no), and prescription of iron and folic acid supplements (yes/no).

\section{Data analysis}

Initially, we evaluated the association of each independent variable with blood hemoglobin levels using linear regression and with presence of anemia using logistic regression. Estimates from these bivariate models were corrected for the complex sampling design using Stata survey commands (svy). Independent variables with $p$-values less than 0.20 were included in multivariate analyses. Multilevel models were used considering three levels: region, village characteristics and household and individual characteristics. For each outcome, four models were adjusted: null model, model 1 (village variables), model 2 (village + household variables), and model 3 (village + household + individual variables). For all multilevel models, random effects were considered for the intercept and intraclass correlation coefficients were estimated for region and village levels.

The xtme family commands were used in the multilevel models. Stata software (v. 12.1) was used for all analyses.

\section{Ethics}

The study protocol and collective consent form were approved by the National Ethics Committee (Comissão Nacional de Ética em Pesquisa - CONEP, authorization number 256/2008) and the National Indian Foundation (Fundação Nacional do Índio - FUNAI). Upon arrival in each village, the research team presented the study objectives and procedures during an open meeting with community leaders and others, preferentially in public, in accordance with each community's protocols for community decision-making. In addition to describing the objectives and procedures of the study, a Free and Informed Collective Consent form was presented in detail. All questions posed by leaders and community members were answered. If a community granted consent, one or more community leaders publicly signed the consent instrument. During visits to households whose residents were not present when the collective consent form was signed by leaders, the study objectives and procedures were explained and questions answered. Any particular village, household, parent, or guardian was allowed to decline to participate at any moment of fieldwork [16]. Under no circumstances were individuals interviewed or measured without their consent.

\section{Results}

Data from 113 villages were obtained (91.9 \% of the original sample). Ten villages were not investigated due to 
refusal, lack of access, cost, and data loss. Of a total of 5674 Indigenous households originally planned, $6.5 \%$ were not interviewed. The main reasons were residents' absence at the time of the field team's visit (5.9\%) and refusal to participate $(0.6 \%)$. The number of interviewed women $(n=6692)$ exceeded what was originally planned $(n=6605)$ because the original list of Indigenous village populations were lower than those encountered during data collection. Hemoglobin measurements were taken for 6651 women $(99.4 \%$ of the total number of women interviewed).

The overall mean hemoglobin level was $12.39 \mathrm{~g} / \mathrm{dL}$ (95 \% CI: 12.29-12.50), with slight differences observed among regions (Fig. 1a). Nationwide anemia prevalence was high (33.0 \%; $95 \%$ CI: 30.40-35.61 \%). Regionally, this prevalence in the North (46.3\%; $95 \%$ CI: 41.30 $51.26 \%$ ) was twice that in the Northeast (22.8\%; $95 \%$ CI: 17.84-27.82 \%) (Fig. 1b). The prevalence in the Southeast/South and Central-West regions were, respectively, $30.8 \%$ (95 \% CI: 25.15-36.49 \%) and $34.8 \%$ (95 \% CI: 31.45-38.25\%).

In the bivariate analysis, village access to community healthcare initiatives was associated with higher mean hemoglobin levels. Other village characteristics were not associated with either hemoglobin levels or anemia (Table 1).
Higher hemoglobin levels and decreased odds of anemia were consistently related to higher household goods, housing condition, and sanitation indices values. No relationship was observed for regular household income. Food patterns were associated with outcomes, both in terms of quantity (presence of seasonal food shortage) and quality (e.g. the wild foods index was a risk factor, while the purchased foods index was protective against anemia) (Table 2).

With regard to individual characteristics, having received malaria treatment was a strong predictor of anemia and hemoglobin levels, while parity was only associated modestly with hemoglobin levels. Overweight and obese women had higher hemoglobin levels and lower anemia prevalence when compared to normal weight women (Table 3). For the subsample of women with children $<5$ years, attending at least one prenatal care consultation was associated with higher hemoglobin levels $(0.29 \mathrm{~g} / \mathrm{dL} ; 95 \% \mathrm{CI}: 0.02-0.57)$, while having received the anti-tetanus vaccine was nominally associated with higher odds of anemia (OR 1.20; $95 \%$ CI: $1.00-1.43)$ in the bivariate analysis. The other antenatal care variables (prescription of iron or folic acid supplement during the most recent pregnancy) were not associated with hemoglobin levels or anemia (data not shown in table).

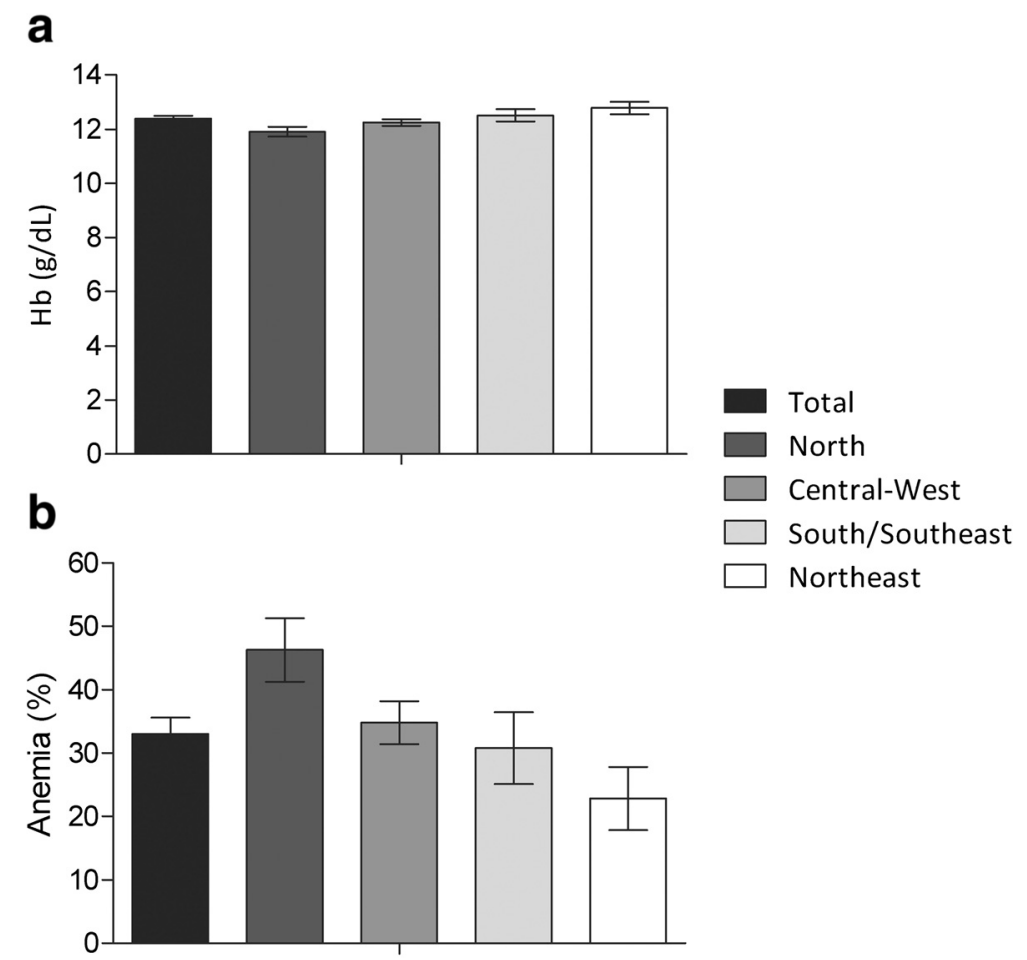

Fig. 1 Mean hemoglobin levels (a) and anemia prevalence (b) with $95 \%$ confidence intervals in Indigenous women according to region. First National Survey of Indigenous People's Health and Nutrition, Brazil, 2008-2009 ( $p$-values $<0.001$ for the association between region and hemoglobin levels or anemia prevalence, obtained from linear and logistic regression, respectively) 
Table 1 Anemia prevalence and mean hemoglobin levels of Indigenous women according to village characteristics. First National Survey of Indigenous People's Health and Nutrition, Brazil, 2008-2009

\begin{tabular}{|c|c|c|c|c|c|}
\hline & \multirow[b]{2}{*}{$\mathrm{n}^{\mathrm{a}}$} & \multicolumn{2}{|l|}{ Anemia } & \multicolumn{2}{|l|}{ Hemoglobin (g/dL) } \\
\hline & & OR $(95 \% \mathrm{Cl})$ & $p$-value ${ }^{*}$ & $\overline{\beta(95 \% \mathrm{Cl})}$ & $p$-value* \\
\hline Indigenous Initiatives Project & & & 0.255 & & 0.547 \\
\hline Yes & 1729 & Reference (1) & & Reference (0) & \\
\hline No & 4809 & $1.16(0.90 ; 1.51)$ & & $-0.07(-0.29 ; 0.15)$ & \\
\hline Indigenous Community Healthcare Initiatives Project & & & 0.130 & & 0.044 \\
\hline Yes & 2090 & Reference (1) & & Reference (0) & \\
\hline No & 4534 & $1.27(0.93 ; 1.72)$ & & $-0.28(-0.55 ;-0.01)$ & \\
\hline Food Acquisition Project & & & 0.681 & & 0.653 \\
\hline Yes & 1733 & Reference (1) & & Reference (0) & \\
\hline No & 4905 & $0.95(0.73 ; 1.23)$ & & $0.05(-0.18 ; 0.28)$ & \\
\hline Population size & & & 0.344 & & 0.224 \\
\hline $1^{\text {st }}$ tertile & 633 & Reference (1) & & Reference (0) & \\
\hline $2^{\text {nd }}$ tertile & 1866 & $0.72(0.47 ; 1.12)$ & & $0.33(-0.04 ; 0.71)$ & \\
\hline $3^{\text {rd }}$ tertile & 3872 & $0.86(0.62 ; 1.20)$ & & $0.16(-0.14 ; 0.45)$ & \\
\hline
\end{tabular}

$O R$ odds ratio, $\mathrm{Cl}$ confidence interval

*Wald Test of heterogeneity

${ }^{a}$ Maximum $\mathrm{N}$ for each category, which may vary between variables due to missing data

The intraclass correlation coefficient (ICC) was 0.12 0.14 for village and $0.04-0.05$ for region level in the null multilevel model. ICC decreased after inclusion of the study variables (ICC village 0.09-0.11; ICC $\mathrm{I}_{\text {region }} 0.02$ ). None of the village-level variables were associated with anemia or hemoglobin levels after controlling for region in the multilevel model (Tables 4 and 5). Likewise, household sanitation condition, seasonal food shortage, and food pattern indices lost significance after controlling for region and village-level variables. Moderate and higher housing condition index scores $\left(2^{\text {nd }}\right.$ tertile), household goods index $\left(2^{\text {nd }}\right.$ and $3^{\text {rd }}$ tertiles), and garden produced index ( $2^{\text {nd }}$ tertile) were associated with higher hemoglobin concentration values. Only the household goods index and wild foods index were associated with anemia. Higher parity was associated with lower hemoglobin values and presence of anemia; current pregnancy was associated with lower hemoglobin levels only. BMI and having received treatment for malaria were associated with both outcomes (Tables 4 and 5). In the subsample of women with children $<5$ years, antenatal care variables (receiving at least one prenatal care consultation and anti-tetanus immunization) were no longer associated with the outcomes in the multivariate model.

\section{Discussion}

The results of the National Survey indicate that approximately one third of Indigenous women in Brazil are anemic. This value is just slightly above that derived from the most recent national prevalence estimate for anemia in non-pregnant Brazilian adult women 15-49 years of age, which was $29.4 \%$ (29.7 \% in urban and $27.9 \%$ in rural areas) [22]. Notwithstanding, while the findings from the National Survey and the 2006 National Demography and Health Survey [22] point to comparable prevalence rates, there are major regional differences, with Indigenous women presenting much higher prevalence of anemia in the North and Central-West regions ( $46.3 \%$ vs. $19.3 \%$ and $34.8 \%$ vs. $20.1 \%$, respectively). Whereas prevalence rates of anemia in Indigenous women and Brazilian women nationally are more similar for the Southeast and South regions, Indigenous women from the Northeast region presented a much lower rate than Brazilian women nationally $(22.8 \%$ vs. $39.1 \%$, respectively). This latter finding is unexpected since the overall socioeconomic and health conditions of Indigenous populations tend to be worse in comparison to the general Brazilian population [16, 23, 24].

The contrasting regional trends observed in the prevalence of anemia among Indigenous women as compared to the general population possibly derive from a complex interplay of socioeconomic, political, and environmental factors [16]. Previous analyses from the National Survey have shown that overall socioeconomic conditions and sanitation infrastructure tend to be better in the Northeast than other regions in Brazil [16]. In addition, Indigenous women in the Northeast presented much higher frequencies of prenatal consultations. For instance, whereas only $33.4 \%$ of Indigenous women in the North 
Table 2 Anemia prevalence and mean hemoglobin levels of Indigenous women according to household characteristics. First National Survey of Indigenous People's Health and Nutrition. Brazil, 2008-2009

\begin{tabular}{|c|c|c|c|c|c|}
\hline & & Anemia Prevalen & & Hemoglobin $(\mathrm{g} / \mathrm{dL}$ & \\
\hline & $n^{a}$ & OR $(95 \% \mathrm{Cl})$ & $p$-value ${ }^{*}$ & $\overline{\beta(95 \% \mathrm{Cl})}$ & $p$-value* \\
\hline Housing condition index & & & 0.001 & & $<0.001$ \\
\hline $1^{\text {st }}$ tertile & 2245 & Reference (1) & & Reference (0) & \\
\hline $2^{\text {nd }}$ tertile & 2160 & $0.78(0.62 ; 0.98)$ & & $0.27(0.12 ; 0.43)$ & \\
\hline $3^{\text {rd }}$ tertile & 2188 & $0.63(0.49 ; 0.80)$ & & $0.43(0.24 ; 0.62)$ & \\
\hline Sanitation index & & & 0.145 & & 0.012 \\
\hline $1^{\text {st }}$ tertile & 2995 & Reference (1) & & Reference (0) & \\
\hline $2^{\text {nd }}$ tertile & 1768 & $0.92(0.71 ; 1.20)$ & & $-0.02(-0.22 ; 0.18)$ & \\
\hline $3^{\text {rd }}$ tertile & 1805 & $0.79(0.63 ; 1.01)$ & & $0.25(0.04 ; 0.46)$ & \\
\hline Purchased foods index & & & $<0.001$ & & $<0.001$ \\
\hline $1^{\text {st }}$ tertile & 2360 & Reference (1) & & Reference (0) & \\
\hline $2^{\text {nd }}$ tertile & 2768 & $0.90(0.77 ; 1.04)$ & & $0.11(-0.02 ; 0.24)$ & \\
\hline $3^{\text {rd }}$ tertile & 1502 & $0.61(0.50 ; 0.75)$ & & $0.42(0.26 ; 0.57)$ & \\
\hline Wild foods index & & & $<0.001$ & & $<0.001$ \\
\hline $1^{\text {st }}$ tertile & 2612 & Reference (1) & & Reference (0) & \\
\hline $2^{\text {nd }}$ tertile & 2873 & $1.48(1.26 ; 1.73)$ & & $-0.26(-0.39 ;-0.13)$ & \\
\hline $3^{\text {rd }}$ tertile & 1145 & $1.80(1.37 ; 2.37)$ & & $-0.49(-0.71 ;-0.27)$ & \\
\hline Garden produced index & & & $<0.001$ & & $<0.001$ \\
\hline $1^{\text {st }}$ tertile & 2199 & Reference (1) & & Reference (0) & \\
\hline $2^{\text {nd }}$ tertile & 2185 & $0.68(0.58 ; 0.79)$ & & $0.31(0.18 ; 0.43)$ & \\
\hline $3^{\text {rd }}$ tertile & 2246 & $0.94(0.79 ; 1.13)$ & & $0.09(-0.05 ; 0.24)$ & \\
\hline Household goods index & & & $<0.001$ & & $<0.001$ \\
\hline $1^{\text {st }}$ tertile & 2234 & Reference (1) & & Reference (0) & \\
\hline $2^{\text {nd }}$ tertile & 2191 & $0.76(0.65 ; 0.89)$ & & $0.23(0.11 ; 0.35)$ & \\
\hline $3^{\text {rd }}$ tertile & 2226 & $0.58(0.47 ; 0.71)$ & & $0.46(0.30 ; 0.63)$ & \\
\hline Regular household income & & & 0.217 & & 0.195 \\
\hline Yes & 3134 & Reference (1) & & Reference (0) & \\
\hline No & 3499 & $1.08(0.95 ; 1.23)$ & & $-0.07(-0.16 ; 0.03)$ & \\
\hline Food shortages & & & 0.026 & & 0.001 \\
\hline Yes & 4673 & Reference (1) & & Reference (0) & \\
\hline No & 1908 & $0.83(0.71 ; 0.98)$ & & $0.16(0.06 ; 0.27)$ & \\
\hline
\end{tabular}

$O R$ odds ratio, $\mathrm{Cl}$ confidence interval

*Wald Test of heterogeneity

${ }^{a}$ Maximum $\mathrm{N}$ for each category, which may vary between variables due to missing data

had at least one prenatal consultation, this proportion was $58.6 \%$ in the Northeast, where $48.3 \%$ of Indigenous women attained a minimum of six consultations during their most recent pregnancy [16]. In fact, half of the variance of anemia prevalence attributed to the regional level was explained after adjusting for socioeconomic, reproductive, and antenatal care indicators.

In order to achieve a broader understanding of potential important factors associated with anemia among Indigenous women, this study addressed both contextual and individual variables. Concerning village characteristics, none of the study variables were associated with anemia or hemoglobin levels in the multivariate model. In relation to household variables, there was a dose-response relationship between the possession of durable household goods and the studied outcomes. Women with higher parity were also more likely to show lower hemoglobin levels. Given a context of high fertility, Indigenous women experience various conditions that might result in anemia, including multiple pregnancies separated by short birth 
Table 3 Anemia prevalence and mean hemoglobin levels of Indigenous women according to individual characteristics. First National Survey of Indigenous People's Health and Nutrition, Brazil, 2008-2009

\begin{tabular}{|c|c|c|c|c|c|}
\hline & & Anemia Prevaler & & Hemoglobin $(\mathrm{g} / \mathrm{d}$ & \\
\hline & $\mathrm{n}^{\mathrm{a}}$ & OR $(95 \% \mathrm{Cl})$ & $p$-value ${ }^{*}$ & $\overline{\beta(95 \% \mathrm{Cl})}$ & $p$-value* \\
\hline Age group (years) & & & 0.250 & & 0.021 \\
\hline $14-19$ & 1691 & Reference (1) & & Reference (0) & \\
\hline $20-34$ & 3468 & $0.95(0.82 ; 1.09)$ & & $0.05(-0.07 ; 0.16)$ & \\
\hline$\geq 35$ & 1492 & $0.88(0.75 ; 1.03)$ & & $0.16(0.03 ; 0.29)$ & \\
\hline Schooling (years) & & & 0.302 & & 0.059 \\
\hline 0 & 998 & Reference (1) & & Reference (0) & \\
\hline $1-4$ & 2597 & $0.97(0.81 ; 1.16)$ & & $0.01(-0.16 ; 0.18)$ & \\
\hline $5-9$ & 1811 & $0.89(0.74 ; 1.08)$ & & $0.13(-0.06 ; 0.32)$ & \\
\hline$\geq 10$ & 1197 & $0.80(0.61 ; 1.05)$ & & $0.19(-0.05 ; 0.42)$ & \\
\hline BMI & & & $<0.001$ & & $<0.001$ \\
\hline Underweight & 183 & $0.78(0.51 ; 1.21)$ & & $0.14(-0.15 ; 0.43)$ & \\
\hline Normal weight & 3618 & Reference (1) & & Reference (0) & \\
\hline Overweight & 1977 & $0.78(0.67 ; 0.92)$ & & $0.14(0.02 ; 0.26)$ & \\
\hline Obese & 845 & $0.62(0.50 ; 0.77)$ & & $0.39(0.23 ; 0.55)$ & \\
\hline Parity & 6621 & $1.03(1.00 ; 1.07)$ & 0.060 & $-0.03(-0.06 ; 0.00)$ & 0.018 \\
\hline Malaria treatment & & & $<0.001$ & & $<0.001$ \\
\hline Yes & 568 & Reference (1) & & Reference (0) & \\
\hline No & 6051 & $0.43(0.29 ; 0.62)$ & & $0.62(0.29 ; 0.96)$ & \\
\hline Current pregnancy & & & 0.277 & & $<0.001$ \\
\hline Yes & 646 & Reference (1) & & Reference (0) & \\
\hline No & 5720 & $0.89(0.73 ; 1.10)$ & & $1.07(0.93 ; 1.20)$ & \\
\hline
\end{tabular}

$O R$ odds ratio, $\mathrm{Cl}$ confidence interval, $\mathrm{BMI}$ Body mass index

*Wald Test of heterogeneity

${ }^{a}$ Maximum $\mathrm{N}$ for each category, which may vary between variables due to missing data

intervals, high prevalence of endemic parasitic infections, food insecurity, and poor prenatal care [25-27].

It is well established that anemia in adult women is closely associated with socioeconomic conditions, including years of schooling. For instance, in Brazil, the prevalence of anemia in adult women decreased with years of schooling. While the prevalence of anemia in women with 0-4 years of schooling was $33.2 \%$, it dropped to $27.8 \%$ among women with $\geq 9$ years of attendance [28]. In this study we observed that neither levels of hemoglobin nor presence of anemia were associated with schooling. It is unclear why no association was found but it might be that the inclusion of other socioeconomic variables, in particular the household goods index, might have obfuscated the influence of years of schooling.

Despite the acknowledged importance of nutrition on hemoglobin levels, there was no consistent evidence of an association between anemia and reported food scarcity or household food consumption and production patterns. However, food security issues are critical among many Indigenous people worldwide and should not be underestimated [29]. In Brazil, Indigenous families that migrate to urban areas often experience major changes in their dietary patterns. In rural areas, Indigenous communities often face strong pressure from the expansion of agriculture, mining, and extractive (e.g. timber) industries or live in reservations located in environmentally degraded regions [16]. Over $90 \%$ of Brazilian Indigenous communities reported some food scarcity during the year and more than $50 \%$ reported such shortages lasted longer than four months [30]. The current economic scenario in Brazil also has affected the subsistence and dietary practices of Indigenous people, either through agricultural intensification and adoption of extractive production or paid work [16]. Thus, while there is broad evidence of food insecurity in Indigenous communities throughout Brazil $[31,32]$, it is possible that the National Survey questionnaire did not have sufficient sensitivity to capture its effects at the individual level. For instance, whereas the present study collected data regarding whether the household experiences seasonally 
Table 4 Mean hemoglobin levels according to village, household and individual level variables. First National Survey of Indigenous People's Health and Nutrition. Brazil, 2008-2009. Geopolitical region was included as a control variable at all levels

\begin{tabular}{|c|c|c|c|c|c|c|}
\hline & \multicolumn{2}{|c|}{ Model 1} & \multicolumn{2}{|c|}{ Model 2} & \multicolumn{2}{|c|}{ Model 3} \\
\hline & $\bar{\beta}$ & $(95 \% \mathrm{Cl})$ & $\bar{\beta}$ & $95 \% \mathrm{Cl}$ & $\bar{\beta}$ & $95 \% \mathrm{Cl}$ \\
\hline \multicolumn{7}{|l|}{ Level 1: Village } \\
\hline Absence of Indigenous Initiatives Project & -0.11 & $(-0.35 ; 0.14)$ & -0.08 & $(-0.32 ; 0.17)$ & -0.11 & $(-0.35 ; 0.13)$ \\
\hline Absence of Indigenous Community Healthcare Initiatives Project & -0.06 & $(-0.29 ; 0.17)$ & -0.05 & $(-0.28 ; 0.18)$ & -0.09 & $(-0.31 ; 0.14)$ \\
\hline Absence of Food Acquisition Project & 0.07 & $(-0.15 ; 0.29)$ & 0.06 & $(-0.16 ; 0.29)$ & 0.06 & $(-0.16 ; 0.28)$ \\
\hline \multicolumn{7}{|l|}{ Level 2: Household characteristics } \\
\hline \multicolumn{7}{|l|}{ Housing condition index } \\
\hline $1^{\text {st }}$ tertile & & & \multicolumn{2}{|c|}{ Reference (0) } & \multicolumn{2}{|c|}{ Reference (0) } \\
\hline $2^{\text {nd }}$ tertile & & & 0.10 & $(0.00 ; 0.20)$ & 0.11 & $(0.00 ; 0.21)$ \\
\hline $3^{\text {rd }}$ tertile & & & 0.06 & $(-0.07 ; 0.18)$ & 0.06 & $(-0.06 ; 0.19)$ \\
\hline \multicolumn{7}{|l|}{ Sanitation index } \\
\hline $1^{\text {st }}$ tertile & & & \multicolumn{2}{|c|}{ Reference (0) } & \multicolumn{2}{|c|}{ Reference (0) } \\
\hline $2^{\text {nd }}$ tertile & & & -0.01 & $(-0.13 ; 0.09)$ & -0.04 & $(-0.15 ; 0.07)$ \\
\hline $3^{\text {rd }}$ tertile & & & -0.02 & $(-0.14 ; 0.11)$ & -0.06 & $(-0.18 ; 0.07)$ \\
\hline \multicolumn{7}{|l|}{ Household goods index } \\
\hline $1^{\text {st }}$ tertile & & & \multicolumn{2}{|c|}{ Reference (0) } & \multicolumn{2}{|c|}{ Reference (0) } \\
\hline $2^{\text {nd }}$ tertile & & & 0.07 & $(-0.02 ; 0.17)$ & 0.08 & $(0.01 ; 0.18)$ \\
\hline $3^{\text {rd }}$ tertile & & & 0.19 & $(0.08 ; 0.30)$ & 0.15 & $(0.03 ; 0.26)$ \\
\hline Absence of regular income & & & -0.05 & $(-0.12 ; 0.03)$ & -0.00 & $(-0.07 ; 0.07)$ \\
\hline Absence of food shortages & & & 0.05 & $(-0.02 ; 0.13)$ & 0.05 & $(-0.03 ; 0.13)$ \\
\hline \multicolumn{7}{|l|}{ Purchased foods index } \\
\hline $1^{\text {st }}$ tertile & & & \multicolumn{2}{|c|}{ Reference (0) } & \multicolumn{2}{|c|}{ Reference (0) } \\
\hline $2^{\text {nd }}$ tertile & & & 0.01 & $(-0.09 ; 0.12)$ & -0.01 & $(-0.12 ; 0.09)$ \\
\hline $3^{\text {rd }}$ tertile & & & 0.05 & $(-0.07 ; 0.17)$ & 0.05 & $(-0.07 ; 0.17)$ \\
\hline \multicolumn{7}{|l|}{ Wild food index } \\
\hline $1^{\text {st }}$ tertile & & & \multicolumn{2}{|c|}{ Reference (0) } & \multicolumn{2}{|c|}{ Reference (0) } \\
\hline $2^{\text {nd }}$ tertile & & & -0.05 & $(-0.16 ; 0.07)$ & -0.00 & $(-0.12 ; 0.10)$ \\
\hline $3^{\text {rd }}$ tertile & & & -0.07 & $(-0.21 ; 0.07)$ & -0.05 & $(-0.19 ; 0.09)$ \\
\hline \multicolumn{7}{|l|}{ Garden produce index } \\
\hline $1^{\text {st }}$ tertile & & & \multicolumn{2}{|c|}{ Reference (0) } & \multicolumn{2}{|c|}{ Reference (0) } \\
\hline $2^{\text {nd }}$ tertile & & & 0.12 & $(0.03 ; 0.21)$ & 0.12 & $(0.03 ; 0.22)$ \\
\hline $3^{\text {rd }}$ tertile & & & -0.04 & $(-0.15 ; 0.07)$ & -0.05 & $(-0.16 ; 0.06)$ \\
\hline
\end{tabular}

Level 3: Individual characteristics

Age group (years)

$$
\begin{aligned}
& \text { 14-19 } \\
& 20-34 \\
& 35-49
\end{aligned}
$$$$
\text { Reference (0) }
$$$$
0.07 \quad(-0.03 ; 0.17)
$$$$
0.11 \quad(-0.03 ; 0.25)
$$

Schooling (years)

$$
0
$$$$
1-4
$$$$
\text { 5-9 }
$$$$
\geq 10
$$

Reference (0)

$\begin{array}{ll}-0.07 & (-0.18 ; 0.04) \\ -0.03 & (-0.16 ; 0.10) \\ -0.07 & (-0.22 ; 0.07)\end{array}$


Table 4 Mean hemoglobin levels according to village, household and individual level variables. First National Survey of Indigenous People's Health and Nutrition. Brazil, 2008-2009. Geopolitical region was included as a control variable at all levels (Continued)

\begin{tabular}{|c|c|c|c|c|c|c|}
\hline \multicolumn{7}{|l|}{$\mathrm{BMI}$} \\
\hline Normal & & & & & \multicolumn{2}{|c|}{ Reference (0) } \\
\hline Underweight & & & & & -0.09 & $(-0.29 ; 0.11)$ \\
\hline Overweight & & & & & 0.15 & $(0.08 ; 0.23)$ \\
\hline Obese & & & & & 0.25 & $(0.14 ; 0.36)$ \\
\hline Parity & & & & & -0.06 & $(-0.09 ;-0.02)$ \\
\hline Absence of malaria treatment & & & & & 0.23 & $(0.09 ; 0.38)$ \\
\hline No current pregnancy & & & & & 0.98 & $(0.87 ; 1.09)$ \\
\hline Intercept & 12.5 & $(12.0 ; 13.0)$ & 12.3 & $(11.8 ; 12.9)$ & 11.3 & $(10.8 ; 11.9)$ \\
\hline Deviance (-2 loglikelihood) & 22513 & & 21832 & & 20361 & \\
\hline ICC village & 0.13 & & 0.12 & & 0.11 & \\
\hline ICC region & 0.04 & & 0.03 & & 0.03 & \\
\hline
\end{tabular}

$\beta$ regression coefficient, $C l$ confidence interval, $B M I$ body mass index Null model $(n=6651)$

Model 1: village (Level 1) $(n=6515)$

Model 2: village (Level 1) + household (Level 2) $(n=6332)$

Model 3: village (Level 1) + household (Level 2) + individual (Level 3) $(n=5998)$

food shortage, the nutritional and socioeconomic determinants of anemia at the individual level might be influenced by factors operating on a broader scale of time.

In contrast with the lack of association between food patterns and anemia, excess weight (i.e., overweight and obesity) showed a protective effect. The relationship between weight and anemia is complex [33]. On the one hand, overweight/obese women might have a greater chance of meeting specific nutrient requirements under food insecure settings due to higher food intake. On the other hand, adiposity is related to chronic inflammation and decreased iron absorption [34,35], which might increase susceptibility to anemia. Population-based studies carried out in low- and middle-income countries have yielded mixed findings, with evidence of both positive $[33,34]$ and negative $[33,36,37]$ associations between weight and anemia.

Having received treatment for malaria, a proxy for malaria infection, was strongly and consistently associated with hemoglobin levels and anemia. Infection with Plasmodium species has a well-known impact on anemia, due to targeting of red blood cells $[38,39]$. Over half of the Indigenous population in Brazil lives in areas of moderate to high risk of malaria transmission [40-42]. Women may face a higher risk of contracting malaria and, during pregnancy, malaria can cause miscarriage, still birth, or delivery of low-birth-weight infants [43]. This is particularly relevant considering that the total fertility rate of Indigenous women in Brazil is much higher than that of the general population, reaching averages close to 4 children per woman $[12,44]$. As the results of this study have shown, higher woman's parity is associated with lower hemoglobin concentration levels and increased presence of anemia. In areas of Plasmodium falciparum transmission, immune suppression induced by anemia favors the evolution of severe clinical malaria, often leading to death.

A recent review of the epidemiology of anemia in Indigenous peoples across the world has indicated iron deficiency, malaria, and helminth infections as the leading causes [45]. Therefore, public health initiatives aiming at reducing the burden of anemia in Indigenous communities should not be limited to the nutritional dimension. Several interventions have proved effective against these types of anemia, such as iron supplementation and food fortification programs, use of insecticide-treated bed-nets for reducing malaria transmission rates, and improved housing and sanitation to reduce both malaria and helminth morbidity [46]. Although these interventions have been implemented as public health initiatives for the general Brazilian population, they are less present in socially marginalized segments, as the Indigenous communities [16].

Some limitations to this study should be taken into account when interpreting its results. The cross-sectional nature of the research design does not allow for the establishment of causal relationships. Moreover, the use of household rather than individual food consumption data precludes dietary analysis of bioavailable iron sources, which is important for understanding the epidemiology of anemia in the study population. Concerning analytical procedures employed in this paper, several study variables, especially social indicators, were chosen based on 
Table 5 Anemia prevalence according to village, household and individual level variables. First National Survey of Indigenous People's Health and Nutrition. Brazil, 2008-2009. Geopolitical region was included as a control variable at all levels

\begin{tabular}{|c|c|c|c|c|c|c|}
\hline & \multicolumn{2}{|c|}{ Model 1} & \multicolumn{2}{|c|}{ Model 2} & \multicolumn{2}{|c|}{ Model 3} \\
\hline & $\mathrm{OR}$ & $(95 \% \mathrm{Cl})$ & $\mathrm{OR}$ & $(95 \% \mathrm{Cl})$ & $\mathrm{OR}$ & $(95 \% \mathrm{Cl})$ \\
\hline \multicolumn{7}{|l|}{ Level 1: Village } \\
\hline Indigenous Community Healthcare Initiatives Project & 1.03 & $(0.76 ; 1.38)$ & 1.01 & $(0.75 ; 1.35)$ & 1.03 & $(0.76 ; 1.38)$ \\
\hline \multicolumn{7}{|l|}{ Level 2: Household characteristics } \\
\hline \multicolumn{7}{|l|}{ Housing condition index } \\
\hline $1^{\text {st }}$ tertile & & & \multicolumn{2}{|c|}{ Reference (1) } & \multicolumn{2}{|c|}{ Reference (1) } \\
\hline $2^{\text {nd }}$ tertile & & & 0.95 & $(0.80 ; 1.12)$ & 0.95 & $(0.80 ; 1.12)$ \\
\hline $3^{\text {rd }}$ tertile & & & 0.93 & $(0.76 ; 1.14)$ & 0.93 & $(0.75 ; 1.13)$ \\
\hline \multicolumn{7}{|l|}{ Sanitation index } \\
\hline $1^{\text {st }}$ tertile & & & \multicolumn{2}{|c|}{ Reference (1) } & \multicolumn{2}{|c|}{ Reference (1) } \\
\hline $2^{\text {nd }}$ tertile & & & 0.99 & $(0.83 ; 1.18)$ & 1.01 & $(0.85 ; 1.21)$ \\
\hline $3^{\text {rd }}$ tertile & & & 1.17 & $(0.96 ; 1.43)$ & 1.19 & $(0.97 ; 1.46)$ \\
\hline \multicolumn{7}{|l|}{ Household goods index } \\
\hline $1^{\text {st }}$ tertile & & & \multicolumn{2}{|c|}{ Reference (1) } & \multicolumn{2}{|c|}{ Reference (1) } \\
\hline $2^{\text {nd }}$ tertile & & & 0.87 & $(0.76 ; 1.01)$ & 0.88 & $(0.76 ; 1.01)$ \\
\hline $3^{\text {rd }}$ tertile & & & 0.71 & $(0.60 ; 0.84)$ & 0.73 & $(0.61 ; 0.87)$ \\
\hline Absence of food shortages & & & 0.93 & $(0.82 ; 1.06)$ & 0.94 & $(0.82 ; 1.07)$ \\
\hline \multicolumn{7}{|l|}{ Purchased foods index } \\
\hline $1^{\text {st }}$ tertile & & & \multicolumn{2}{|c|}{ Reference (1) } & \multicolumn{2}{|c|}{ Reference (1) } \\
\hline $2^{\text {nd }}$ tertile & & & 0.94 & $(0.80 ; 1.11)$ & 0.95 & $(0.81 ; 1.13)$ \\
\hline $3^{\text {rd }}$ tertile & & & 0.95 & $(0.78 ; 1.16)$ & 0.95 & $(0.78 ; 1.16)$ \\
\hline \multicolumn{7}{|l|}{ Wild food index } \\
\hline $1^{\text {st }}$ tertile & & & \multicolumn{2}{|c|}{ Reference (1) } & \multicolumn{2}{|c|}{ Reference (1) } \\
\hline $2^{\text {nd }}$ tertile & & & 1.25 & $(1.05 ; 1.50)$ & 1.24 & $(1.04 ; 1.49)$ \\
\hline $3^{\text {rd }}$ tertile & & & 1.15 & $(0.92 ; 1.43)$ & 1.17 & $(0.94 ; 1.46)$ \\
\hline \multicolumn{7}{|l|}{ Garden produce index } \\
\hline $1^{\text {st }}$ tertile & & & \multicolumn{2}{|c|}{ Reference (1) } & \multicolumn{2}{|c|}{ Reference (1) } \\
\hline $2^{\text {nd }}$ tertile & & & 0.88 & $(0.75 ; 1.02)$ & 0.88 & $(0.75 ; 1.02)$ \\
\hline $3^{\text {rd }}$ tertile & & & 1.04 & $(0.87 ; 1.24)$ & 1.04 & $(0.87 ; 1.25)$ \\
\hline
\end{tabular}

Level 3: Individual characteristics

Age group (years)

$$
\begin{aligned}
& \text { 14-19 } \\
& 20-34
\end{aligned}
$$$$
\text { 35-49 }
$$

Reference (1)

0.98

$(0.83 ; 1.16)$

0.93

$(0.74 ; 1.16)$

Schooling (years)

0

$1-4$

5-9

$\geq 10$
Reference (1)

1.07

1.06

$(0.86 ; 1.30)$

1.06

$(0.83 ; 1.35)$
$(0.89 ; 1.27)$ 
Table 5 Anemia prevalence according to village, household and individual level variables. First National Survey of Indigenous People's Health and Nutrition. Brazil, 2008-2009. Geopolitical region was included as a control variable at all levels (Continued)

\begin{tabular}{|c|c|c|c|c|}
\hline \multicolumn{5}{|l|}{$\mathrm{BMI}$} \\
\hline \multicolumn{2}{|l|}{ Normal } & & \multicolumn{2}{|c|}{ Reference (1) } \\
\hline Underweight & & & 1.00 & $(0.71 ; 1.40)$ \\
\hline Overweight & & & 0.80 & $(0.69 ; 0.90)$ \\
\hline Obese & & & 0.73 & $(0.59 ; 0.87)$ \\
\hline Parity & & & 1.06 & $(1.00 ; 1.11)$ \\
\hline Absence of malaria treatment & & & 0.66 & $(0.53 ; 0.82)$ \\
\hline Deviance (-2 loglikelihood) & 8192 & 7909 & 7748 & \\
\hline ICC village & 0.11 & 0.10 & 0.09 & \\
\hline ICC region & 0.04 & 0.03 & 0.02 & \\
\hline
\end{tabular}

OR: odds ratio, $\mathrm{Cl}$ : confidence interval, $B M I$ : body mass index

Null model $(n=6651)$

Model 1: village (Level 1) $(n=6624)$

Model 2: village (Level 1) + household (Level 2) $(n=6443)$

Model 3: village (Level 1) + household (Level 2) + individual (Level 3) $(n=6351)$

evidence of anemia determinants in non-Indigenous societies and therefore may not be similarly relevant for this Indigenous population.

\section{Conclusion}

This study reports for the first time on the prevalence of anemia and associated factors among Indigenous women of childbearing age in Brazil based on a nationwide representative sample. Anemia prevalence was slightly higher among Indigenous women than has been documented for women in the general Brazilian population, suggesting they are somewhat disadvantaged in terms of nutritional and overall health. This study also reveals a scenario of marked disparities in anemia prevalence between regions, with nearly half of Indigenous women in northern Brazil being affected. The occurrence of low hemoglobin levels and anemia among Indigenous women are associated with well-known factors, such as socioeconomic status, food patterns, nutritional status, parity, and exposure to malaria. However, part of the variability in these outcomes remains unexplained, which might derive from specific ecological and socioeconomic conditions pertaining to this ethnically differentiated population. Further research on risk factors and potential determinants of anemia among Indigenous communities is essential to guide public policies and health-nutritional interventions aimed at controlling the burden of anemia in these populations.

\section{Abbreviations}

BMI: body mass index; Cl: confidence interval; CONEP: Comissão Nacional de Ética em Pesquisa; FUNAl: Fundação Nacional do Índio; FUNASA: Fundação Nacional de Saúde.

\section{Competing interests}

The authors declare that they have no competing interests.
Authors' contributions

RVS, AMC, JRW, LG, CEAC, and BLH participated in designing the research. RVS, AMC, JRW, LG, CEAC, and BLH participated in field data collection. MCB, RB, and BLH conducted statistical analyses. MCB, RVS, JRW, and CEAC wrote the manuscript and all other authors read and commented on it. The final paper submitted for publication was read and approved by all authors.

\section{Acknowledgements}

The Brazilian Ministry of Health and the World Bank provided financial support through the Vigisus II project. Equipment was provided by FUNASA and the Escola Nacional de Saúde Pública (ENSP). Support and assistance were offered by Indigenous leaders and community members in all of the villages surveyed, the project's team leaders and research assistants, and the staff at local FUNASA and FUNAI offices.

\section{Author details}

${ }^{1}$ Programa de Pós-Graduação em Epidemiologia, Departamento de Medicina Social, Faculdade de Medicina, Universidade Federal de Pelotas, Rua Marechal Deodoro 1160, Pelotas, RS 96001-970, Brazil. ${ }^{2}$ Escola Nacional de Saúde Pública, Fundação Oswaldo Cruz, Rua Leopoldo Bulhões 1480, Rio de Janeiro, RJ 21041-210, Brazil. ${ }^{3}$ Departamento de Antropologia, Museu Nacional, Universidade Federal do Rio de Janeiro, Quinta da Boa Vista s/n, Rio de Janeiro, RJ 20940-040, Brazil. ${ }^{4}$ Centro de Pesquisas Leônidas e Maria Deane, Fundação Oswaldo Cruz, Rua Terezina 476, Manaus, AM 69057-070, Brazil.

Received: 5 May 2015 Accepted: 27 January 2016

Published online: 01 February 2016

\section{References}

1. Bernoist B, McLean E, Egli I, Cogswell M, editors. Worldwide prevalence of anaemia 1993-2005: WHO Global Database on anaemia. Geneva: The World Health Organization; 2008.

2. Stevens GA, Finucane MM, De-Regil LM, Paciorek CJ, Flaxman SR, Branca F, et al. Global, regional, and national trends in haemoglobin concentration and prevalence of total and severe anaemia in children and pregnant and non-pregnant women for 1995-2011: a systematic analysis of populationrepresentative data. Lancet Glob Health. 2013;1:e16-25.

3. Allen LH. Anemia and iron deficiency: effects on pregnancy outcome. Am J Clin Nutr. 2000;71(5 Suppl):1280S-4S.

4. Victora CG, Aquino EML, Leal MC, Monteiro CA, Barros FC, Szwarcwald CL. Maternal and child health in Brazil: progress and challenges. Lancet. 2011; 377:1863-76.

5. Paim J, Travassos C, Almeida C, Bahia L, Macinko J. The Brazilian health system: history, advances, and challenges. Lancet. 2011;377:1778-97. 
6. Coimbra Jr CEA, Santos RV. Emerging health needs and epidemiological research in indigenous peoples in Brazil. In: Salzano FM, Hurtado AM, editors. Lost Paradises and the Ethics of Research and Publication. Oxford: Oxford University Press; 2004. p. 89-109.

7. Coimbra Jr CEA. Saúde e povos indígenas no Brasil: reflexões a partir do I Inquérito Nacional de Saúde e Nutrição Indígena. Cad Saude Publica. 2014; 30:855-9.

8. Cardoso MA, Scopel KK, Muniz PT, Villamor E, Ferreira MU. Underlying factors associated with anemia in Amazonian children: a population-based, crosssectional study. PLoS One. 2012;7:e36341.

9. Leite MS, Santos RV, Coimbra Jr CEA, Gugelmin AS. Alimentação e nutrição dos povos indígenas no Brasil. In: Kac G, Sichieri R, Gigante DP, editors. Epidemiologia Nutricional. Rio de Janeiro: Editora Fiocruz; 2007. p. 503-18.

10. Leite MS, Cardoso AM, Coimbra Jr CEA, Welch JR, Gugelmin SA, Lira PCl, et al. Prevalence of anemia and associated factors among indigenous children in Brazil: results from the First National Survey of Indigenous People's Health and Nutrition. Nutr J. 2013;12:69

11. Pagliaro H, Azevedo M, Santos RV. Demografia dos povos indígenas no Brasil: um panorama crítico. In: Pagliaro H, Azevedo M, Santos RV, editors. Demografia dos Povos Indígenas no Brasil. Rio de Janeiro: Editora Fiocruz; 2005. p. 11-32.

12. Wong L, Morell MN, Carvalho R. Notas sobre o comportamento reprodutivo da população autodeclarada indígena - Censos Demográficos 1991 e 2000. Rev Bras Estud Popul. 2009;26:61-7.

13. Santos RV, Bastos JL, Cruz OG, Longo LAFB, Flowers NM, Pereira NOM. Parity of Indigenous and non-Indigenous women in Brazil: does the reported number of children born depend upon who answers National Census questions? PLoS One. 2015;10:e0123826.

14. Leite MS, Gugelmin SA, Santos RV, Coimbra Jr CEA. Perfis de saúde indígena, tendências nacionais e contextos locais: reflexões a partir do caso Xavánte. In: Coimbra Jr CEA, Santos RV, Escobar AL, editors. Epidemiologia e Saúde dos Povos Indígenas no Brasil. Rio de Janeiro: Editora Fiocruz; 2003. p. 105-25.

15. Orellana JDY, Cunha GM, Santos RV, Coimbra Jr CEA, Leite MS. Prevalência e fatores associados à anemia em mulheres indígenas Suruí com idade entre 15 e 49 anos, Amazônia, Brasil. Revista Brasileira de Saúde Materno Infantil. 2011;11:153-61.

16. Coimbra Jr CEA, Santos RV, Welch JR, Cardoso AM, Souza MC, Garnelo L, et al. The First National Survey of Indigenous People's Health and Nutrition in Brazil: rationale, methodology, and overview of results. BMC Public Health. 2013;13:52.

17. Lemeshow S, Hosmer D, Klar J, Lwanga SK. Adequacy of sample size in health studies. Chichester, England: John Wiley \& Sons; 1990.

18. Ohlsson E. Sequential Poisson sampling. J Off Stat. 1998;14:149-62.

19. World Health Organization. Physical status: the use and interpretation of anthropometric indicators of nutritional status. Geneve: The World Health Organization; 1995.

20. Cole TJ, Bellizzi MC, Flegal KM, Dietz WH. Establishing a standard definition for child overweight and obesity worldwide: international survey. BMJ. 2000 320:1240-3.

21. Cole TJ, Flegal KM, Nicholls D, Jackson AA. Body mass index cut offs to define thinness in children and adolescents: international survey. BMJ. 2007:335:166-7.

22. Ministério da Saúde. Pesquisa Nacional de Demografia e Saúde da Criança e da Mulher - PNDS 2006: Dimensões do processo reprodutivo e da saúde da criança. Série G: Estatística e Informação em Saúde. Brasilia: Ministério da Saúde; 2009

23. Garnelo L, Macedo G, Brandão LC. Os povos indígenas e a construção das políticas de saúde no Brasil. Brasilia: Organização Pan-Americana de Saúde; 2003.

24. Cardoso AM, Santos RV, Coimbra Jr CEA. Mortalidade infantil segundo raça/ cor no Brasil: o que dizem os sistemas nacionais de informação? Cad Saude Publica. 2005;21:1602-8.

25. Brabin L, Brabin BJ. Parasitic infection in women and their consequences. Adv Parasitol. 1992;31:1-81.

26. Dellicour S, Tatem AJ, Guerra CA, Snow RW, ter Kuile FO. Quantifying the number of pregnancies at risk of malaria in 2007: a demographic study. PLoS Med. 2010;7:e1000221.

27. Martinez-Espinosa FE, Daniel-Ribeiro CT, Alecrim WD. Malaria during pregnancy in a reference centre from the Brazilian Amazon: unexpected increase in the frequency of Plasmodium falciparum infections. Mem Inst Oswaldo Cruz. 2004;99:19-21

28. Instituto Brasileiro de Geografia e Estatística. Pesquisa Nacional por Amostra de Domicílios. um panorama da saúde no brasil: acesso e utilização dos serviços, condições de saúde e fatores de risco e proteção à saúde - 2008. Rio de Janeiro: Instituto Brasileiro de Geografia e Estatística; 2010.
29. Gracey M, King M. Indigenous health part 1: determinants and disease patterns. Lancet. 2009:374:65-75.

30. Associação Brasileira de Saúde Coletiva. Inquérito Nacional de Saúde e Nutrição dos Povos Indígenas. Relatório Final. Rio de Janeiro: Associação Brasileira de Saúde Coletiva (ABRASCO); 2010.

31. Segall-Corrêa AM, Azevedo MMA, Ferreira MBR, Kepple AW, León-Marin L. Perception of food insecurity among indigenous Guarani communities in the state of São Paulo, Brazil. FASEB J. 2010;24(Suppl):104-6.

32. Fávaro T, Ribas DLB, Zorzatto JR, Segal-Corrêa AM, Panigassi G. Segurança alimentar em famílias indígenas Teréna, Mato Grosso do Sul, Brasil. Cad Saude Publica. 2007:23:785-93.

33. Aderibigbe OR, Pisa PT, Vorster HH, Kruger SH. The relationship between iron status and adiposity in women from developing countries: a review. Crit Rev Food Sci Nutr. 2014;54:553-60.

34. Cepeda-Lopez AC, Osendarp SJ, Melse-Boonstra A, Aeberli I, Gonzalez-Salazar F, Feskens E, et al. Sharply higher rates of iron deficiency in obese Mexican women and children are predicted by obesity-related inflammation rather than by differences in dietary iron intake. Am J Clin Nutr. 2011;93:975-83.

35. Zimmermann MB, Zeder C, Muthayya S, Winichagoon P, Chaouki N, Aeberli I, et al. Adiposity in women and children from transition countries predicts decreased iron absorption, iron deficiency and a reduced response to iron fortification. Int J Obes (Lond). 2008:32:1098-104.

36. Baig-Ansari N, Badruddin SH, Karmaliani R, Harris H, Jehan I, Pasha O, et al. Anemia prevalence and risk factors in pregnant women in an urban area of Pakistan. Food Nutr Bull. 2008;29:132-9.

37. Balarajan YS, Fawzi WW, Subramanian SV. Changing patterns of social inequalities in anaemia among women in India: cross-sectional study using nationally representative data. BMJ Open. 2013;3:e002233.

38. Gamain B, Smith JD, Viebig NK, Gysin J, Scherf A. Pregnancy-associated malaria: parasite binding, natural immunity and vaccine development. Int J Parasitol. 2007;37:273-83.

39. Gosling RD, Hsiang MS. Malaria and severe anemia: thinking beyond Plasmodium falciparum. PLoS Med. 2013;10:e1001576.

40. Souza-Santos R, Oliveira MVG, Escobar AL, Santos RV, Coimbra Jr CEA. Spatial heterogeneity of malaria in Indian reserves of southwestern Amazonia, Brazil. Int J Health Geogr. 2008;7:55.

41. de Castro MC, Monte-Mor RL, Sawyer DO, Singer BH. Malaria risk on the Amazon frontier. Proc Natl Acad Sci USA. 2006;103:2452-7.

42. Garnelo L, Brandão LC, Levino A. Dimensões e potencialidades dos sistemas de informação geográfica na saúde indígena. Rev Saude Publica. 2005;39:634-40.

43. Chagas ECS, Nascimento CT, Santana-Filho FS, Bôtto-Menezes CH, MartinezEspinosa FE. Malária durante a gravidez: efeito sobre o curso da gestação na região amazônica. Rev Panam Salud Publica. 2009;26:203-8.

44. Instituto Brasileiro de Geografia e Estatística. Censo Demográfico 2010: nupcialidade, fecundidade e migração. Resultados da amostra. Rio de Janeiro: Instituto Brasileiro de Geografia e Estatística; 2012.

45. Khambalia AZ, Aimone AM, Zlotkin SH. Burden of anemia among indigenous populations. Nutr Rev. 2011;69:693-719.

46. Balarajan Y, Ramakrishnan U, Özaltin E, Shankar AH, Subramanian SV. Anaemia in low-income and middle-income countries. Lancet. 2011;378: 2123-35.

\section{Submit your next manuscript to BioMed Central and we will help you at every step:}

- We accept pre-submission inquiries

- Our selector tool helps you to find the most relevant journal

- We provide round the clock customer support

- Convenient online submission

- Thorough peer review

- Inclusion in PubMed and all major indexing services

- Maximum visibility for your research

Submit your manuscript at www.biomedcentral.com/submit
Biomed Central 